too, perhaps, are the figures of 18 introduced species included in the following 150 pages devoted to illustrations of 75 species, although ten genera recorded for the state are omitted.

Each species is contained in one opening; common and scientific names, drawings of hair types found on the rump and photomicrographs selected to show sections, parts of whole mounts and scale patterns are included to show 'the most diagnostic characters'. They serve also to underline the difficulties, not least of which are the numerous types of hairs to be found on one animal and the variations in pattern along a single hair. Even with their years of experience the authors find it difficult to distinguish between some genera, and distinctions between species are usually even more subtle. A key to instant, indisputable identification of pelts and parts used in manufactured goods is what taxonomists, conservationists and customs officials alike hope for; unhappily it is not yet available.

J. M. INGLES

\title{
Ornithology from Aristotle to the Present, by Erwin Stresemann. Harvard University Press, $£ 11.00$.
}

Erwin Stresemann (1889-1972) was himself a world-leader in ornithology and wrote with great authority. This book was published in German in 1951 and has now been well translated into English by $H$. J. and C. Epstein and edited by G. W. Cottrell. The author's distinguished disciple, Ernst Mayr of Harvard, contributes a foreword and a valuable epilogue entitled 'Materials for a history of American ornithology' (up to date).

It is a very readable book, full of fascinating information about people and ideas. The first chapter leads us from classical times to the Renaissance. Aristotle, who was born in 384 B.C., laid the foundations of scientific ornithology, but strangely mixed his facts with fanciful notions taken at secondhand. His authority for the view that the detailed study of birds was a worthy occupation for the philosophic mind was cited as justification for the studies in the Middle Ages of such natural scientists as the Emperor Frederick II, Belon, Gesner and Aldrovandi. A stimulus to exotic ornithology was given by travellers returning from America; when Columbus made his ceremonial entry into Barcelona in 1493 he astonished the onlookers by parading 'molti papagalli' (parrots). And two domesticated species of American Indian origin, the turkey and the Muscovy duck, were introduced into Europe.

Chapters 3-15 constitute Part Two under the general heading of 'The development of systematics and the study of evolution'. Here, among many others, we read of Willughby and Ray, of Linnaeus and his opponent Buffon; and of the formal systematists in their last stand against the theory of evolution. The final six chapters constitute Part Three, under the heading 'The development of biology', and include one on the reform of the theory of behaviour.

The book is enriched by scholarship and enlivened by wit. The author's sympathies are shown by the remark in his preface that 'ornithology has ever required the service not only of the intellect, but of the heart'.

A. LANDSBOROUGH THOMSON

The Seas, by F. S. Russell and C. M. Yonge. Warne, $£ 6.95$.

It is a pleasure to welcome the fourth edition 'completely revised, extended and reset' of this classic that was first published nearly fifty years ago. Much has been learnt about the seas and the life in them during those five decades, and the authors have brought their text up to date to include the essence of the new knowledge. The format, larger than in previous editions, gives greater scope for the plates, 